\title{
Length at Age, Sexual Maturity and Distribution of Atlantic Halibut, Hippoglossus hippoglossus L., off the Northeast USA
}

\author{
Douglas B. Sigourney and Michael R. Ross \\ Department of Natural Resources Conservation, University of \\ Massachusetts, Holdsworth Hall, Amherst, MA 01003, USA \\ Jon Brodziak and Jay Burnett \\ National Marine Fisheries Service, Northeast Fisheries Science Center \\ 166 Water Street, Woods Hole, MA 02543, USA
}

Sigourney, D. B., M. R. Ross, J. Brodziak, and J. Burnett. 2006. Length at age, sexual maturity and distribution of Atlantic halibut, Hippoglossus hippoglossus L., off the Northeast USA. J. Northw. Atl. Fish. Sci., 36: 81-90. doi: 10.2960/J.v36.m574

\begin{abstract}
This paper presents first estimates of length at age, size and age at sexual maturity, and depth distributions of Atlantic halibut (Hippoglossus hippoglossus L.) off the Northeast USA. The estimates are based on samples collected from spring and autumn bottom trawl surveys in the Gulf of Maine-Georges Bank region (1976-2000) and an experimental longline fishery off the coast of Maine (2000-2001). Longlines targeted larger, faster growing fish than a bottom trawl indicating gear selectivity. Sexual dimorphism in growth was apparent with females attaining greater sizes after age 4. Median age at maturity was estimated to be 6.0 years for males and 7.3 years for females. Adult halibut $(>80 \mathrm{~cm})$ occurred at greater average depths than juveniles $(<40 \mathrm{~cm})$, but mean depth of capture differed among seasons for all size-classes of halibut. The results suggest that halibut from the Gulf of Maine-Georges Bank region grow faster than those from the Newfoundland-Labrador region. Median ages at maturity of male and female halibut were lower than in other regions of the Northwest Atlantic; however, lengths at maturity were similar.
\end{abstract}

Key words: Age at maturity, Atlantic halibut, distribution, growth

\section{Introduction}

The Atlantic halibut (Hippoglossus hippoglossus L.) is a commercially valuable flatfish that is distributed throughout the North Atlantic. Halibut represent the largest and longest lived flatfish capable of growing to sizes of over $220 \mathrm{~cm}$ and living to ages of older than 50 years (Bigelow and Schroeder, 1953; Haug, 1990). In addition to these life history characteristics, Atlantic halibut are also slow to mature (Bigelow and Schroeder, 1953). As a consequence many fish are harvested before they can reproduce rendering it susceptible to even moderate levels of fishing pressure. Abundance of the Atlantic halibut stock off the Northeast USA has declined severely over the past century (Anon., 2002). Halibut stocks in the Gulf of Maine showed clear signs of overexploitation as early as the 1870s (Goode and Collins, 1887; Scudder, 1887). Annual landings from the Gulf of Maine-Georges Bank region averaged 662 metric tons (mt) during 18931940, declined to an average of $144 \mathrm{mt}$ during 1941-76, and have reached historic lows of $17 \mathrm{mt}$ in recent years (Anon., 2002). At present, there is no directed harvest of halibut off the Northeast USA.
A number of studies have described the growth and behavior of Atlantic halibut stocks in the northwest Atlantic (Bowering, MS 1986; Neilson and Bowering, 1989; Neilson et al., 1989; Haug, 1990; Neilson et al., 1993). There have been no corresponding studies of the population in USA waters and the Gulf of MaineGeorges Bank region represents the southern most extent of the geographic range of this species. Thus, life history and population characteristics may differ significantly from more northern populations that have been the focus of past studies. The present study aims at estimating some general biological parameters of Atlantic halibut in the Gulf of Maine-Georges Bank region, that so far have not been available, emphasizing on length at age, maturity at age and length, as well as describing depth distribution of juveniles and adults. We then compare information from this study to other populations of Atlantic halibut in the North Atlantic.

\section{Materials and Methods}

To investigate the biology of Atlantic halibut in the Gulf of Maine we used all available information 
collected from NEFSC bottom trawl survey cruises. The bottom trawl survey employs a random stratified sampling design using depth zones as strata (Grosslein, 1969; Azarovitz, 1981). Data on Atlantic halibut in the survey database extend back as far as 1963; however, an archive collection of otoliths samples only extends back to 1977 (Table 1). Because otolith samples were limited, we pooled all available information across years to estimate age of individual fish.
To help supplement the archived collection of otoliths, we included more recent samples collected from an experimental longline fishery off Vinal Haven, Maine in the Penobscot Bay region of the Gulf of Maine. This two year fishery allowed up to four commercial fishing boats to set longlines for halibut in federal waters between 15 April and 15 June, in 2000 and 2001 (Table 1). Each vessel was limited to a total of 700 circular hooks no smaller than 14/0 inch size. The fishermen extracted otoliths

TABLE 1. Number of samples and source of collection for information used in this study. Data were collected through a combination of NEFSC bottom trawl surveys (NEFSC) and an experimental longline fishery off of Maine (EF). Data from the survey database were used in the distribution analysis, otolith samples were used in all other analyses.

\begin{tabular}{|c|c|c|c|c|c|}
\hline \multicolumn{3}{|c|}{ Survey Database } & \multicolumn{3}{|c|}{ Otolith Samples } \\
\hline Date & Source & No. of Samples & $\overline{\text { Date }}$ & Source & No. of Samples \\
\hline 1963 & NEFSC & 53 & - & - & - \\
\hline 1964 & NEFSC & 73 & - & - & - \\
\hline 1965 & NEFSC & 33 & - & - & - \\
\hline 1966 & NEFSC & 27 & - & - & - \\
\hline 1967 & NEFSC & 5 & - & - & - \\
\hline 1968 & NEFSC & 14 & - & - & - \\
\hline 1969 & NEFSC & 29 & - & - & - \\
\hline 1970 & NEFSC & 32 & - & - & - \\
\hline 1971 & NEFSC & 49 & - & - & - \\
\hline 1972 & NEFSC & 90 & - & - & - \\
\hline 1973 & NEFSC & 91 & - & - & - \\
\hline 1974 & NEFSC & 239 & - & - & - \\
\hline 1975 & NEFSC & 129 & - & - & - \\
\hline 1976 & NEFSC & 105 & - & - & - \\
\hline 1977 & NEFSC & 127 & 1977 & NEFSC & 59 \\
\hline 1978 & NEFSC & 136 & 1978 & NEFSC & 68 \\
\hline 1979 & NEFSC & 78 & 1979 & NEFSC & 70 \\
\hline 1980 & NEFSC & 80 & 1980 & NEFSC & 77 \\
\hline 1981 & NEFSC & 57 & 1981 & NEFSC & 29 \\
\hline 1982 & NEFSC & 16 & 1982 & NEFSC & 1 \\
\hline 1983 & NEFSC & 22 & 1983 & NEFSC & 2 \\
\hline 1984 & NEFSC & 14 & 1984 & - & - \\
\hline 1985 & NEFSC & 16 & 1985 & - & - \\
\hline 1986 & NEFSC & 20 & 1986 & NEFSC & 1 \\
\hline 1987 & NEFSC & 25 & 1987 & - & - \\
\hline 1988 & NEFSC & 13 & 1988 & NEFSC & 7 \\
\hline 1989 & NEFSC & 12 & 1989 & NEFSC & 10 \\
\hline 1990 & NEFSC & 32 & 1990 & NEFSC & 17 \\
\hline 1991 & NEFSC & 42 & 1991 & NEFSC & 28 \\
\hline 1992 & NEFSC & 13 & 1992 & NEFSC & 2 \\
\hline 1993 & NEFSC & 18 & 1993 & NEFSC & 8 \\
\hline 1994 & NEFSC & 11 & 1994 & - & - \\
\hline 1995 & NEFSC & 18 & 1995 & - & - \\
\hline 1996 & NEFSC & 15 & 1996 & - & - \\
\hline 1997 & NEFSC & 14 & 1997 & - & - \\
\hline 1998 & NEFSC & 21 & 1998 & - & - \\
\hline 1999 & NEFSC & 15 & 1999 & - & - \\
\hline 2000 & NEFSC & 10 & 2000 & $\mathrm{EF}$ & 75 \\
\hline 2001 & - & - & 2001 & $\mathrm{EF}$ & 76 \\
\hline
\end{tabular}


from a total of 151 legal sized halibut ( $\geq 36$ inches or 91.4 $\mathrm{cm}$ ) for the purpose of age determination, and recorded total length $(\mathrm{cm})$ and sex. In total, 530 otolith samples were aged in this study.

Age determination. To age otoliths we used the same approach that is employed by the NEFSC age and growth laboratory to age witch flounder (Glyptocephalus cynoglossus), another long-lived flatfish in the Gulf of Maine (Penttila et al., MS 1988). Because whole saggital otoliths of halibut are difficult to interpret under magnification otoliths were processed and aged using a thin section approach. Otoliths were sectioned transversely along the dorso-lateral axis. Thin sections of otoliths were viewed using reflected light under a dissecting scope at a magnification of $12 \times$. Distinct age banding patterns that consisted of white opaque zones and dark hyaline zones were apparent under microscopy (Fig. 1). All ages were assigned according to the number of hyaline zones counted in the thin sections by the first author. Although this method has not been validated for Atlantic halibut, it has been validated for Pacific halibut (Hippoglossus stenolepis) (Piner and Wischniowski, 2004) and is consistent with the aging method employed by the International Pacific Halibut Commission (IPHC) for Pacific halibut (Anon., 1987). In addition, it is also consistent with the aging method used in other studies of Atlantic halibut (Devold, 1938; Jakupsstovu and Haug, 1988). To assess the precision of age estimates we took a blind read approach using a subsample of 237 otoliths. A more experienced age reader from the NEFSC served as the primary age reader and the first author was the secondary age reader. To assess precision among readers, we regressed the age determinations of the primary

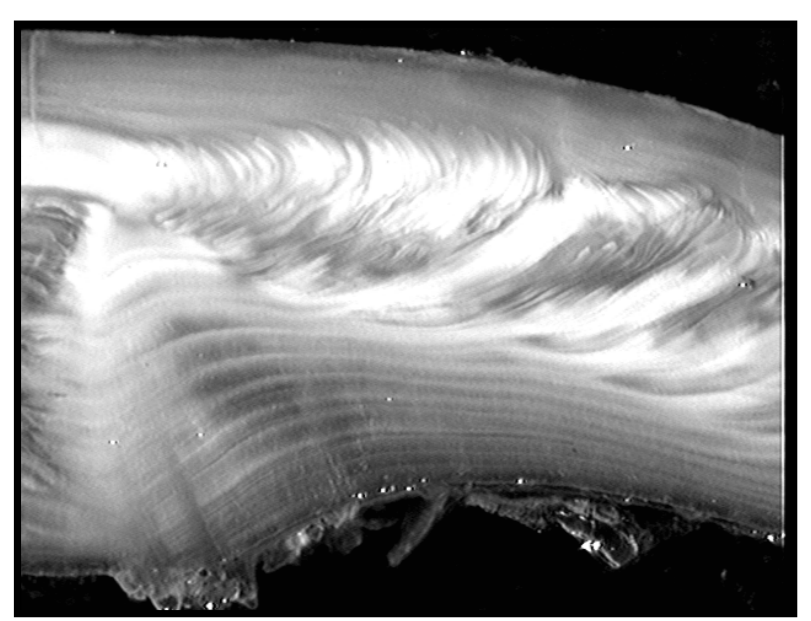

Fig. 1. Picture of a sectioned Atlantic halibut (Hippoglossus hippoglossus) otolith at $12 \times$ magnification. Age was estimated to be 11 years. age reader on the age determinations of the secondary age reader (Campana et al., 1995). We also calculated the index of average percentage error (IAPE) (Beamish and Fournier, 1981). Although this method can be flawed (Hoenig et al., 1995) an assessment of the raw data indicated this method should adequately describe precision in our age estimates. The formula described by Beamish and Fournier (1981) is as follows:

$$
I A P E=\frac{100}{N} \sum_{j=1}^{R}\left[\frac{1}{R} \sum_{i=1}^{R} \frac{\left|X_{i j}-X_{j}\right|}{X_{j}}\right]
$$

where $N=$ the number of fish aged;

$R=$ the number of readings;

$X_{i j}=$ the mean age of the $j^{\text {th }}$ fish at the $i^{\text {th }}$ reading; and

$X_{j}=$ the mean age calculated for the $j^{\text {th }}$ fish.

All age estimates determined by the experienced age reader were used in the analysis $(n=237)$. The remaining samples were cross-read by the first author up to three times using a blind read approach until within reader agreement was realized.

Length at age. As previously mentioned, data used in the growth analysis came from two different sources, a bottom trawl survey and a longline fishery, over different time periods. Unfortunately, because both changes in environmental conditions and differences in gears types could influence length at age, we cannot combine these data sets to model growth. To investigate possible different in length at age between the two sources of data we compared the length at age data collected in the bottom trawl surveys with the more recent data from the experimental longline fishery. We applied a Wilcoxon 2-sample sign test to each age-class to test for significant differences in length. To assess whether or not there was evidence of size-selectivity among sampling gears we graphically compared length frequency distributions between the two sources of data.

Maturity. Gonads were examined macroscopically at sea and assigned to one of six possible maturity stages (Burnett et al., MS 1989). Color of the gonad and size in relation to body cavity size are among the most important criteria for determining maturity. Stage I indicates an immature fish while all higher stages indicate a mature fish at some level of gonadal development.

We used probit analysis to estimate median length $\left(L_{50}\right)$ and age $\left(A_{50}\right)$ at maturity (Finney, 1971; Trippel and Harvey, 1991). The fit of the probit model to the raw data 
was analyzed with goodness-of-fit tests by calculating Chi-square values. Lengths and ages at median maturity were calculated for each sex.

Distribution. Information on the depth distributions of adult and juvenile halibut was derived from the NEFSC bottom trawl survey data. Research survey data on Atlantic halibut date back to 1963 and include information on trawl depth, as well as latitude and longitude for each capture. The data were collected from 1963 to 2000 during spring, summer, autumn and winter months in bottom trawl surveys conducted by the NEFSC (Fig. 2). Prior to 1968, data were collected solely during autumn months (Azarovitz, 1981). Using these data we evaluated the hypothesis that different size-classes of halibut are segregated by habitat preferences. Due to small sample sizes, we combined data from all years under the assumption that the patterns of distribution of Atlantic halibut with respect to depth have remained constant over time. We partitioned the samples into the following size-classes: juveniles $(<40 \mathrm{~cm})$; subadults $(40-80 \mathrm{~cm})$; adults $(>80 \mathrm{~cm})$. The sub-adult class was included because halibut within this size range may switch their feeding habits to become more piscivorous, but are not yet sexually mature (Bigelow and Schroeder, 1953).
We investigated differences in depth distribution between size categories by applying a Kruskal-Wallis nonparametric ANOVA (Sokal and Rohlf, 1981) for each season in which halibut were caught. We also investigated temporal (seasonal) patterns of distribution within each size-class by applying a Kruskal-Wallis non-parametric ANOVA to each size-class separately.

\section{Results}

Age determination. Percent agreement between readers was $60 \%$, which is comparable to the average percent agreement achieved by the International Pacific Halibut Commission (J. Forsberg, International Pacific Halibut Commission, pers. comm.). Age estimates that did not agree differed by an average of approximately 1.4 years for all years combined. The average IAPE was $6.8 \%$. Results from the regression analysis indicated systematic over-aging by the first author (secondary age reader) as evidenced by an intercept that was significantly greater than one (Fig. 3). We feel this systematic bias was mainly the result of misinterpretation of the last annulus by the first author for samples of smaller halibut collected in the autumn. This bias was adjusted for in later age readings by not counting the last annulus for samples collected in the autumn. All samples that did not

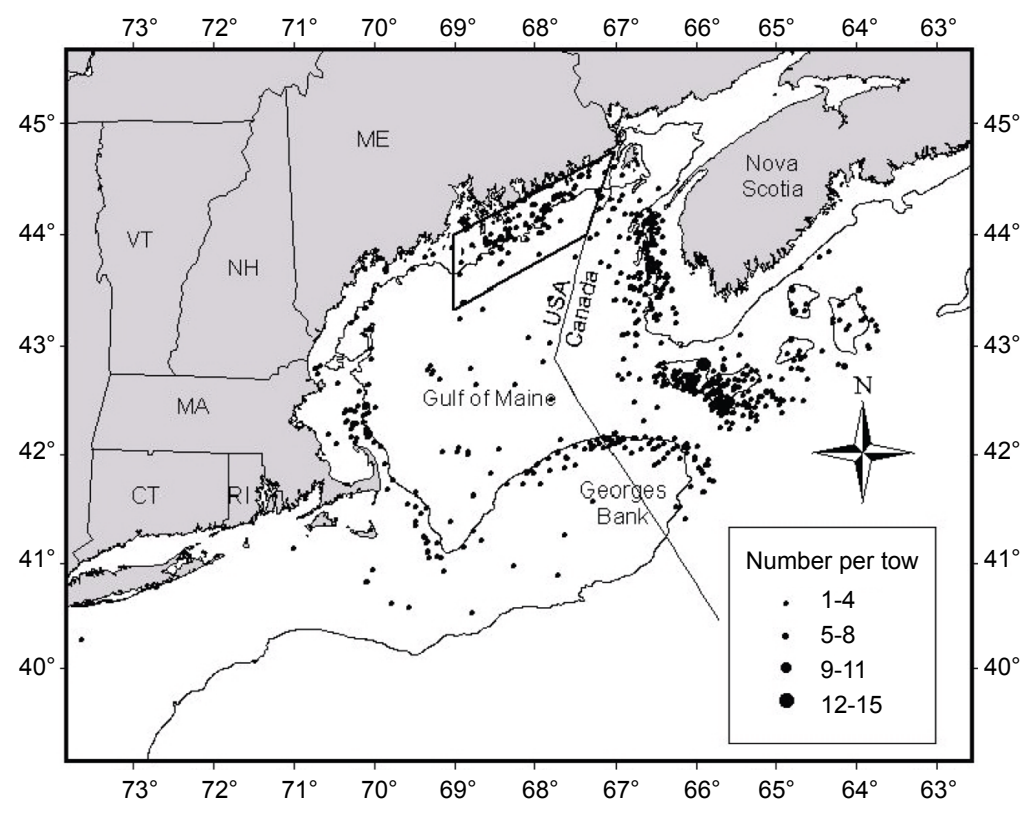

Fig. 2. Map of the Gulf of Maine-Georges Bank region showing the distribution of all Atlantic halibut (Hippoglossus hippoglossus) caught in spring, autumn and winter bottom trawl surveys conducted by the Northeast Fisheries Science Center from 1963 to the present. The polygon represents the general area where the experimental longline fishery was conducted during the spring months of 2000 and 2001. The distribution of samples from this fishery is not shown. 


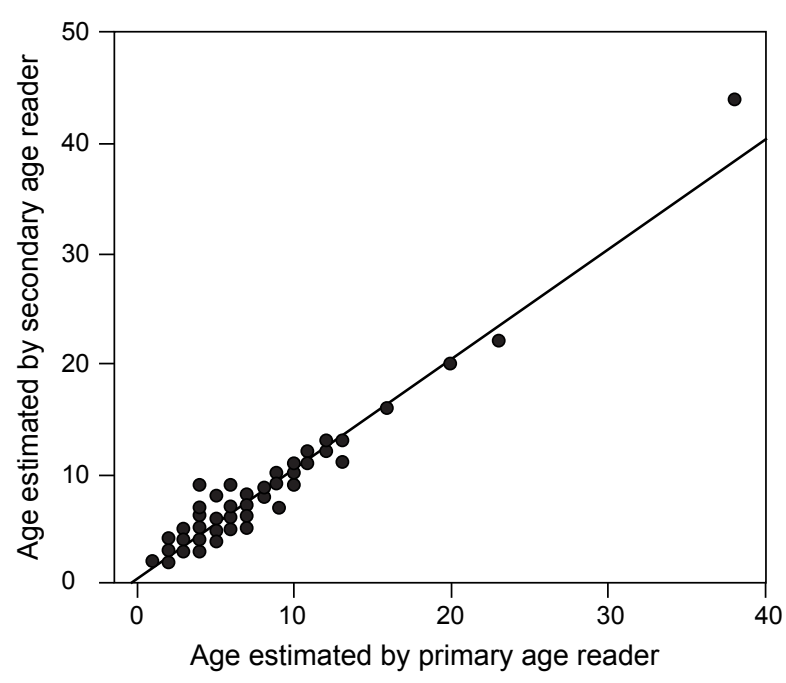

Fig. 3. Scatter plot of ages for Atlantic halibut (Hippoglossus hippoglossus) estimated by the experienced age reader (primary age reader) $v s$ ages estimated by the first author (secondary age reader). Results of a linear regression indicated the slope (1.001) was not significantly different from 1 but the intercept $(0.399)$ was significantly different from $0(P<0.05)$.

agree were re-read up to three times by the first author until within reader agreement was reached.

Length at Age. A comparison of samples from the experimental fishery with NEFSC survey samples suggested a difference in size at age between the two sets of samples for both females (Fig. 4a) and males (Fig. 4b). Fish from the experimental fishery attained larger lengths at age than fish caught in the bottom trawl survey. Differences in mean length at age ranged from $2.8 \mathrm{~cm}$ for 8 year old fish to $29.5 \mathrm{~cm}$ for 5 year old fish in males and $12.7 \mathrm{~cm}$ for 11 year old fish to $28.8 \mathrm{~cm}$ for 5 year old fish in females. Wilcoxon 2-sample rank tests indicated significant differences in length at age for all age-classes that included sample sizes of $n>5$ (Fig. 4). A histogram of mean size of captured fish indicated a difference in the size-classes targeted by the two gear types (Fig. 5). The bottom trawl appeared to capture mostly small $(<80 \mathrm{~cm})$ fish where as the longline was able to capture a noticeably greater proportion of large $(>80 \mathrm{~cm})$ fish.

Maturity. Results from the maturity analysis indicated that females tend to mature at larger sizes than males. The length at median maturity $\left(L_{50}\right)$ was $103 \mathrm{~cm}$ for females and $80 \mathrm{~cm}$ for males (Table 2). Females also mature at older ages than males. Age at median maturity $\left(A_{50}\right)$ was 7.3 for females and 6.0 for males (Table 2). The observed proportion mature was not significantly different from the probit model for male $\left(\chi^{2}=0.41, P=\right.$

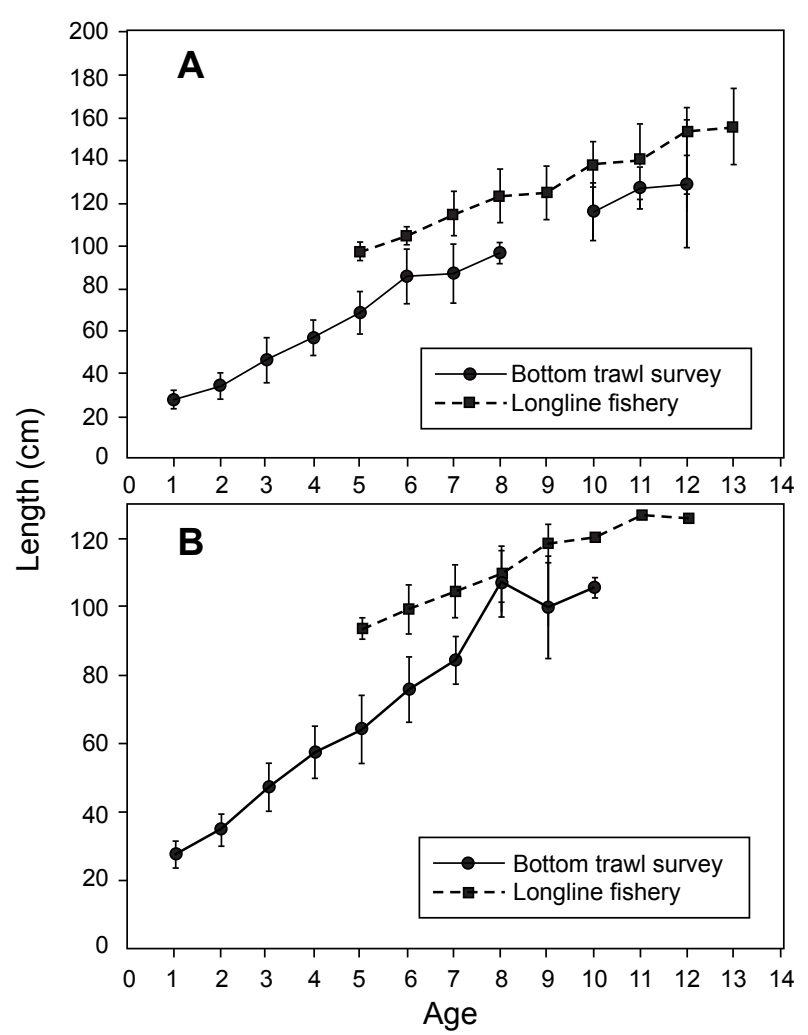

Fig. 4. Differences in average length at age between (A) female and (B) male Atlantic halibut caught (Hippoglossus hippoglossus) in NEFSC bottom trawl surveys, 1977-2000 and female and male Atlantic halibut caught in an experimental longline fishery, 2000-2001. Error bars represent \pm 1 standard deviation from the mean. A Wilcoxon 2-sample test indicated significant differences in length for age-classes 5-7 for males and 5-8 and 10 for females.

$0.25)$ and female $\left(\chi^{2}=10.97, P=0.69\right)$ age at maturity data and for male $\left(\chi^{2}=108.94, P=0.91\right)$ and female $\left(\chi^{2}\right.$ $=143.13, P=0.74)$ length at maturity data. Sex ratios showed that females were more prevalent in the larger size-classes. The proportion of males to females was approximately 1.1:1 for both the juvenile $(<40 \mathrm{~cm})$ and subadult $(40-80 \mathrm{~cm})$ size-classes. In the adult size-class $(>80 \mathrm{~cm})$ however, the proportion of males to females is $1: 2.3$. Thus, there appear to be proportionally more females in the older age-classes, consistent with dimorphic growth patterns.

Distribution. Significant temporal changes in average depth distributions were evident for all size-classes (Table 3). Adult fish were found at greater depths in the autumn and shallower depths in the summer. Subadults were found at greater depths in the spring than during the other seasons. Juveniles were found at shallower depths in the summer than during the other seasons. 


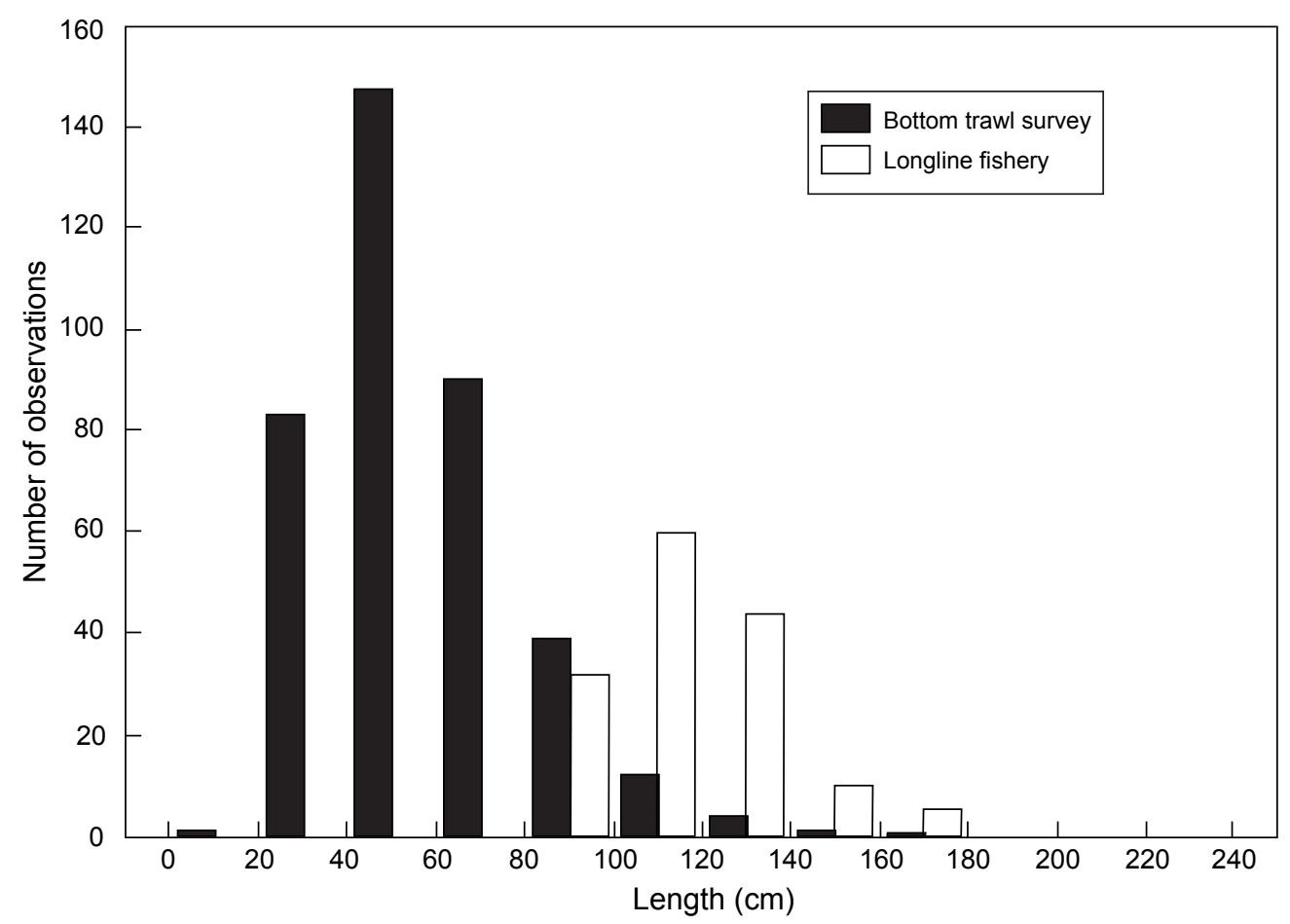

Fig. 5. Length-frequency distribution of Atlantic halibut caught in NEFSC bottom trawl surveys between 1977 and $2000(n=379)$ and an experimental longline fishery $(n=151)$ between 2000 and 2001 in the Gulf of Maine.

TABLE 2. Estimated ages and lengths at $10 \%, 25 \%, 50 \%, 75 \%$ and $99 \%$ maturity predicted from a probit analysis for male and female Atlantic halibut (Hippogolssus hippoglossus) in the Gulf of Maine. Standard errors are provided below estimates.

\begin{tabular}{|c|c|c|c|c|c|c|}
\hline & $n$ & $L_{01}$ or $A_{01}$ & $L_{25}$ or $A_{25}$ & $L_{50}$ or $A_{50}$ & $L_{75}$ or $A_{75}$ & $L_{99}$ or $A_{99}$ \\
\hline \multicolumn{7}{|l|}{ Age } \\
\hline Males & 201 & $\begin{array}{c}-0.18 \text { years } \\
(0.92)\end{array}$ & $\begin{array}{c}4.23 \text { years } \\
(0.31)\end{array}$ & $\begin{array}{c}6.04 \text { years } \\
(0.37)\end{array}$ & $\begin{array}{c}7.84 \text { years } \\
(0.62)\end{array}$ & $\begin{array}{c}12.25 \text { years } \\
(1.36)\end{array}$ \\
\hline Females & 233 & $\begin{array}{c}-0.02 \text { years } \\
\quad(0.92)\end{array}$ & $\begin{array}{c}5.17 \text { years } \\
(0.33)\end{array}$ & $\begin{array}{c}7.29 \text { years } \\
(0.41)\end{array}$ & $\begin{array}{c}9.41 \text { years } \\
(0.66)\end{array}$ & $\begin{array}{c}14.61 \text { years } \\
\quad(1.40)\end{array}$ \\
\hline \multicolumn{7}{|l|}{ Length } \\
\hline Males & 201 & $\begin{array}{c}11.06 \mathrm{~cm} \\
(9.38)\end{array}$ & $\begin{array}{c}60.19 \mathrm{~cm} \\
(3.38)\end{array}$ & $\begin{array}{c}80.24 \mathrm{~cm} \\
(3.94)\end{array}$ & $\begin{array}{c}100.30 \mathrm{~cm} \\
(6.33)\end{array}$ & $\begin{array}{c}149.42 \mathrm{~cm} \\
(13.66)\end{array}$ \\
\hline Females & 232 & $\begin{array}{c}13.03 \mathrm{~cm} \\
(10.64)\end{array}$ & $\begin{array}{c}76.91 \mathrm{~cm} \\
(4.14)\end{array}$ & $\begin{array}{c}102.99 \mathrm{~cm} \\
(4.78)\end{array}$ & $\begin{array}{c}129.07 \mathrm{~cm} \\
(7.40)\end{array}$ & $\begin{array}{c}192.94 \mathrm{~cm} \\
(15.59)\end{array}$ \\
\hline
\end{tabular}

Significant differences in the vertical (depth) distributions of size-classes were evident for spring, summer and autumn, but not for winter (Table 3). In the spring, juvenile fish were found at shallower average depths than adult fish. In the summer, juvenile fish were again found at shallower average depths than adult fish; however, the difference in average depth was not as pronounced. In the autumn, the difference in average depth between juveniles and adults increased, where juveniles continued to exploit shallower habitats than adults. Subadults were found at intermediate depths in all three seasons. 
TABLE 3. Mean seasonal depth distribution of three different size-classes of Atlantic halibut (Hippogolssus hippoglossus) in the Gulf of Maine. Range of depths and sample sizes are indicated below means. Kruskal-Wallis tests indicated significant differences in seasonal depth distribution for all three size-classes $(* P<0.05, * * P<0.01, * * * P<0.0001)$ and significant differences in depth among size-classes in all seasons except winter $(* P<0.05, * * P<0.01, * * * P<0.0001)$.

\begin{tabular}{ccccc}
\hline \hline & Spring *** & Summer* & Autumn *** & Winter \\
\hline $\begin{array}{c}\text { Juvenile* } \\
(<40 \mathrm{~cm})\end{array}$ & $88 \mathrm{~m}$ & $79 \mathrm{~m}$ & $84 \mathrm{~m}$ & $89 \mathrm{~m}$ \\
& $n=146$ & $(17-262 \mathrm{~m})$ & $(38-173 \mathrm{~m})$ & $(40-124 \mathrm{~m})$ \\
& $n=100$ & $n=113$ & $n=22$ \\
Subadult*** & $100 \mathrm{~m}$ & $92 \mathrm{~m}$ & $94 \mathrm{~m}$ & $93 \mathrm{~m}$ \\
& & & & \\
$(40-80 \mathrm{~cm})$ & $(29-310 \mathrm{~m})$ & $(24-310 \mathrm{~m})$ & $(31-516 \mathrm{~m})$ & $(46-201 \mathrm{~m})$ \\
& $n=370$ & $n=208$ & $n=390$ & $n=77$ \\
Adult** & $114 \mathrm{~m}$ & $97 \mathrm{~m}$ & $128 \mathrm{~m}$ & $106 \mathrm{~m}$ \\
$(>80 \mathrm{~cm})$ & $(36-212 \mathrm{~m})$ & $(31-280 \mathrm{~m})$ & $(61-297 \mathrm{~m})$ & $(56-177 \mathrm{~m})$ \\
& $n=54$ & $n=31$ & $n=54$ & $n=20$ \\
\hline
\end{tabular}

\section{Discussion}

Our size-at-age data indicated faster growth rates for halibut caught in the experimental longline fishery versus halibut caught in bottom trawl surveys. This disparity may be an artifact of gear selectivity. The majority (85\%) of fish caught in the bottom trawl survey were smaller than $80 \mathrm{~cm}$, where as the longline fishery caught a substantially greater proportion of fish larger than 80 $\mathrm{cm}$. Similar length dependent patterns in gear selectivity between trawl gear and longline gear have been demonstrated for both Pacific halibut (H. stenolepis) (Trumble et al., 1993; Kaimmer, 1999) and Atlantic halibut (Anon., 1999). Gear selectivity can be problematic when trying to estimate demographic parameters not only because different gears can exclude certain sizeclasses but also because it can select for faster growing individuals within an age-class (Lucena and O'Brien, 2001; Potts and Manooch, 2002). Thus, results from this study should be interpreted cautiously when characterizing the growth dynamics of the current halibut fishery.

Although gear selectivity may play a significant role in observed differences in length at age we also cannot rule out possible effects of environmental variation. The majority of the halibut samples from the bottom trawl survey were collected in the late 1970s from various locations throughout the Gulf of Maine. In contrast, samples from the longline fishery were collected more recently and in a relatively small geographic area. Thus, spatial and temporal variation in water temperature, food availability and density may also have influenced differences in growth rates. Temporal variation in growth of Atlantic halibut have been reported in other studies (Haug and Tjemsland, 1986), and may be a source of variation in these data.

A comparison of growth to other regions of the North Atlantic suggest that halibut in the Gulf of Maine attain larger lengths at age than halibut from Newfoundland-Labrador region of Canada (Bowering, MS 1986) but similar lengths ate age as halibut from Faroese waters between Scotland and Iceland (Jakupstovvu and Haug, 1988). To control for effects of gear we used only data from the bottom trawl survey. Spatial heterogeneity in growth patterns has been demonstrated among populations of Atlantic halibut in the North Atlantic (Joensen, 1954; McCracken, 1958). Because the Gulf of Maine represents the southern extent of halibut in the western Atlantic they may experience faster growth rates than halibut from more northern waters due to a longer growing season. The similarity in growth rates between Faroese waters and the Gulf of Maine is intriguing considering the vast difference in geographic location particularly in regard to latitude. Similarity in environmental factors such as food availability and water may reduce variation in growth among these regions. An alternative explanation may be countergradient variation (Levins, 1969). For example, Jonassen et al. (2000) found that halibut from more northerly regions off of Norway and Iceland had a greater capacity for growth than halibut from more southerly regions off of eastern Canada. This phenomenon has been demonstrated in a number of species (Conover and Present, 1990; Conover et al., 
1997) and is known to reduce the phenotypic variation among populations of fish distributed along a latitudinal gradient.

The observed spatial differences in growth are consistent with differing interpretations of Atlantic halibut stock structure. For example, Stobo et al. (1988) found that halibut are capable of substantial movements, thus, it is possible that the Gulf of Maine-Georges Bank stock may be part of a larger metapopulation extending from Georges Bank to Newfoundland waters. If Atlantic halibut in the Northwest Atlantic are part of a metapopulation, observed differences in halibut growth between the Gulf of Maine and more northerly Canadian waters may represent a phenotypically plastic response to different growing conditions. In contrast, Wise and Jensen (1959) found that the majority of Atlantic halibut tagged in the Gulf of Maine were recaptured close (within 30 miles) to the area of tagging. Also, Foss et al. (1998) used genetic evidence to demonstrate that stocks in the eastern Atlantic may be reproductively isolated from one another. Therefore, halibut from the Gulf of Maine-Georges Bank region could also represent a genetically distinct stock that grows faster and matures earlier than halibut from Newfoundland-Labrador region. Regardless of the actual mechanism, observed differences in growth patterns should be considered in the development of fishery management plans in each region.

Similar to other studies (Devold, 1938; Joensen, 1954; McCracken, 1958; Haug and Tjemsland, 1986), we found evidence of sexual dimorphism in growth in Atlantic halibut. Females tended to reach larger lengths at age than males particularly after age 4. Similarly, Bowering (MS 1986) found that females begin to attain larger lengths at age after age 6 . This dimorphism may be attributable to the positive relationship between fecundity and body size, which favors maintained growth in female flatfish after they mature (Roff, 1982; Jakupsstovu and Haug, 1988).

Median ages at maturity of male and female halibut were lower than reported for Atlantic halibut in other studies (Jespersen, 1917; McCracken, 1958); however, lengths at maturity were similar. McCracken (1958) found that halibut caught in waters off the east coast of Canada in the 1940s reached maturity between 8 and 10 years of age at a median length of $80 \mathrm{~cm}$ for males and between 10 and 12 years of age at a median length of $110 \mathrm{~cm}$ for females. Jespersen (1917) found similar results for male and female Atlantic halibut caught in Icelandic waters. However, our results are comparable to those presented by Jakupsstovu and Haug
(1988) for female Atlantic halibut $\left(A_{50}=7\right.$ years., $L_{50}=$ $110-115 \mathrm{~cm})$ caught in Faroese waters north of Scotland. This decrease in age at maturity may be related to increases in growth. Maturity is highly correlated with growth in flatfish (Roff, 1982). A decrease in the age of maturity over time is evident in other populations of Atlantic halibut throughout the North Atlantic and is often concomitant with a decline in halibut density due to exploitation (Haug and Tjemsland, 1986). Because the halibut stock in the Gulf of Maine-Georges Bank region is depleted, it is possible that density-dependent growth may be responsible for observed differences in size and median age at maturity among regions.

Female Atlantic halibut mature at older ages and larger sizes than males in the Gulf of Maine-Georges Bank region. This result is consistent with findings from other studies on Atlantic halibut (Jakupstsstovu and Haug, 1988; Devold, 1938) as well as other flatfish species (Burnett et al., 1992; Brodziak and Mikus, 2000). The increase in fitness due to the strong, positive relationship between fecundity and size provides an adaptive advantage for females that continue to grow after maturity (Roff, 1982). The adaptive advantage of continued growth may not be as strong for males since they allocate less energy to reproduction.

The pattern of distribution of Atlantic halibut in the Gulf of Maine-Georges Bank region is consistent with patterns of distribution reported from other studies in the North Atlantic (Scott, 1982; Haug and Sundby, 1987; Godo and Haug, 1988a; Godo and Haug, 1988b). In general, larger adults seem to prefer deeper waters than smaller juveniles with subadults occupying intermediate depths. Reasons for this disparity in distribution may be related to ontogenetic niche shifts in diet. Kohler (1967) found that juveniles $<30 \mathrm{~cm}$ in length eat invertebrates almost exclusively where adults $>80 \mathrm{~cm}$ feed almost exclusively on fish. Also, there is evidence that mature halibut will spawn in deep water and the bathypelagic eggs may drift inshore to shallow water nursery grounds (Devold, 1938; Mathisen and Olsen, 1968; Haug and Tjemsland, 1986; Jakupsstovu and Haug, 1988). Evidence of this deep water spawning behavior is apparent in the seasonal distribution of adults. Nielson et al. (1993) found that peak spawning in Canadian waters occurs in November and December, which was contrary to previous studies that suggested that spawning occurs in the spring. Although there is some anecdotal evidence that Atlantic halibut spawn in the spring in the Gulf of Maine (Bigelow and Schroeder, 1953), adult halibut in the Gulf of Maine are also found at the deepest depths in the autumn, which may be part of a spawning migration. 
In a general comparison, Pacific and Atlantic halibut appear to share a similar pattern of growth and distribution throughout their range. In particular, Pacific halibut caught in more northerly waters around Alaska grow slower and mature at older ages than fish from more southerly waters (Trumble et al., 1993). Also, the established conceptual model for distribution of Pacific halibut begins with spawning in deep water, dispersal of larvae in inshore waters and general movements out to deeper feeding grounds as fish grow and mature (Trumble et al., 1993). Consistent with this general model, we found evidence of juveniles distributed in shallower waters than mature adults. The similarity between the biology of Pacific halibut in terms of growth and age at maturity suggest that the successful management of Pacific halibut could serve as a general model for conservation and management of stocks in the Gulf of Maine. In contrast to Pacific halibut, obtaining detailed information on potential Atlantic halibut spawning areas, reproduction, and egg and larval dispersal in the Gulf of MaineGeorges Bank region will be challenging given the depleted status of this stock.

\section{Acknowledgements}

The authors would like to extend thanks to the many people who helped make this study possible. We are grateful for the help of Betty Holmes and all the members of The Northeast Fisheries Science Center's age and growth lab who helped section otoliths. We are also thankful for the many helpful comments provided by Kevin Friedland, Steve Murawski and three anonymous reviewers. This study was funded by the UMASS/NOAA Cooperative Marine Education Research Program.

\section{References}

ANON. 1987. The Pacific Halibut: Biology, Fishery and Management. IPHC Tech. Rep. No. 22 International Pacific Halibut Commission, P.O. Box 95009, Seattle, WA 98105-2009.

1999. Atlantic halibut of the Gulf of St. Lawrence (Divisions 4RST). DFO Sci. Stock Status Rep., A4-02. $9 \mathrm{p}$.

2002. Assessment of 20 Northeast groundfish stocks through 2001: a report of the Groundfish Assessment Review Meeting (GARM), Northeast Fisheries Science Center, Woods Hole Massachusetts, October 8-11, 2002. Northeast Fish. Sci. Cent. Ref. Doc., 02-16, 511 p.

AZAROVITZ, T. R. 1981. A brief historical view of the the Woods Hole laboratory trawl survey time series. In: Bottom trawl surveys. W.G. Doubleday and D. Rivard (eds). Can. Spec. Publ. Fish. Aquat. Sci., 58: 62-67.

BEAMISH, R. J., and D. A. FOURNIER. 1981. A method for comparing the precision of a set of age determinations. Can. J. Fish. Aquat. Sci., 38: 982-983.
BIGELOW, H. B., and W. C. SCHROEDER. 1953. Fishes of the Gulf of Maine. Fish. Bull., 53: 577 p.

BOWERING, W. R. MS 1986. The distribution, age and growth, and sexual maturity of Atlantic Halibut (Hippoglossus hippoglossus) in the Newfoundland and Labrador area of the Northwest Atlantic. Can. Tech. Rep. Fish. Aquat. Sci., No. 1432.

BRODZIAK, J., and R. MIKUS. 2000. Variation in life history parameters of Dover sole, Microstomus pacificus, off the coast of Washington, Oregon, and northern California. Fish. Bull., 98: 661-673.

BURNETT, J., L. O'BRIEN, R. K. MAYO, J. A. DARDE, and M. BOHAN. MS 1989. Finfish maturity sampling and classification schemes used during Northeast Fisheries Science Center bottom trawl surveys, 1963-1989. Northeast Fisheries Science Center, 166 Water Street, Woods Hole, MA 02543-1026, NOAA Tech. Mem., NMFS-F/ NEC-76, $14 \mathrm{p}$.

BURNETT, J., M. R. ROSS, and S. H. CLARK. 1992. Several biological aspects of the witch flounder (Glyptocephalus cynaglossus (L.)) in the Gulf of Maine-Georges Bank region. J. Northw. Atl. Fish Sci., 12: 15-25.

CAMPANA, S. E., C. M. ANNAND, and J. I. MCMILLAN. 1995. Graphical and statistical methods for determining the consistency of age determinations. Trans. Am. Fish. Soc., 124: 131-138.

CONOVER, D. O. and T. M. C. PRESENT. 1990. Countergradient variation in growth rate: compensation for length of the growing season among Atlantic silversides from different latitudes. Oecologia, 83: 316-324.

CONOVER, D. O., J. J. BROWN, and A. EHTISHAM. 1997. Countergradient variation in growth of young striped bass (Morone saxatilis) from different latitudes. Can. J. Fish. Aquat. Sci., 54: 2401-2409.

DEVOLD, F. 1938. The North Atlantic halibut and net fishing. FiskDir. Skr. Ser. HavUnders., V: 1-47.

FINNEY, D. J. 1971. Probit Analysis. $3^{\text {rd }}$ ed. Cambridge University Press, $333 \mathrm{p}$.

FOSS, A., K. IMSLAND, and G. NAEVDAL. 1998. Population genetics of the Atlantic halibut in the North Atlantic Ocean. J. Fish. Biol., 53: 901-905.

GODO, O. R., and T. HAUG. 1988a. Tagging and recapture of Atlantic halibut (Hippoglossus hippoglossus) in Norwegian waters. J. Cons. Int. Explor. Mer., 44: 169-179.

1988b. Tagging and recapture of Atlantic halibut (Hippoglossus hippoglossus L.) on the continental shelves of Eastern Canada, and off Western and Eastern Greenland. J. Northw. Atl. Fish. Sci., 8: 25-31.

GOODE, G. B., and J. W. COLLINS. 1887. The fresh-halibut fishery. In: The fisheries and fishery industry of the United States. Section V. History and methods of the fisheries, Vol. I, Part I. The halibut fisheries. Government Printing Office, Washington, DC. p. 3-89.

GROSSLEIN, M. D. 1969. Groundfish surveys of the Bureau of Commercial Fisheries, Woods Hole. Comm. Fish. Rev., 31(7): 22-25.

HAUG, T. 1990. Biology of the Atlantic halibut, Hippoglossus hippoglossus (L., 1758). Adv. Mar. Biol., 26: 1-70.

HAUG, T., and S. SUNDBY. 1987. A preliminary report on 
the natural occurrence and ecology of Atlantic halibut, Hippoglossus hippoglossus, postlarvae and young immature stages. Council Meeting of the International Council of the Exploration of the Sea F38: 22 p. (mimeo).

HAUG, T., and J. TJEMSLAND. 1986. Changes in size- and age-distributions and age at sexual maturity in Atlantic halibut, Hippoglossus hippoglossus, caught in North Norwegian waters. Fish. Res., 4: 145-155.

HOENIG, J. M., M. J. MORGAN, and C. A. BROWN. 1995. Analysing differences between two age determination methods by tests of symmetry. Can. J. Fish. Aquat. Sci., 52: $364-368$.

JAKUPSSTOVU, S. H. I., and T. HAUG. 1988. Growth, sexual maturation, and spawning season of Atlantic halibut, Hippoglossus hippoglossus, in Faroese waters. Fish. Res., 6: 201-215.

JESPERSEN, P. 1917. Contribution to the life history of the North Atlantic halibut (Hippoglossus vulgaris Flem.). Medd. Kommn. Dan. Fisk. Havunders., Ser. Fisk., 10(5): $1-36$.

JOENSEN, J. S. 1954. On the life history of halibut in Faroe waters. Medd. Dan. Fisk. Havunders., N.S., 1(5): 1-25.

JONASSEN, T. M., A. K. IMSLAND, R. FITZGERALD, S. W. BONGA, E. V. HAM, G. NAEVDAL, M. O. STEFANSSON, and S. O. STEFANSSON. 2000. Geographic variation in growth and food conversion efficiency of juvenile Atlantic halibut related to latitude. J. Fish. Biol., 56: 279-294.

KAIMMER, S. M. 1999. Direct observations on the hooking behavior of Pacific halibut, Hippoglossus stenolepis. Fish. Bull., 97: 873-883.

KOHLER, A. C. 1967. Size at maturity, spawning season, and food of Atlantic halibut. J. Fish. Res. Board Can., 24: 53-66.

LEVINS, R. 1969. Thermal acclimation and heat resistance in Drosophila species. Am. Nat., 103: 483-499.

LUCENA, F. M., and C. M. O'BRIEN. 2001. Effects of gear selectivity and different calculation methods on estimating growth parameters of bluefish, Pomatomus saltatrix (Pisces: Pomatomidae), from southern Brazil. Fish. Bull., 99: $432-442$.

MATHISEN, O. A., and S. OLSEN. 1968. Yield isopleths of the halibut, Hippoglossus hippoglossus, in Northern Norway. FiskDir. Skr. Ser. HavUnders., 14: 129-159.

MCCRACKEN, F. D. 1958. On the biology and fishery of the Canadian Atlantic halibut (Hippoglossus hippoglossus L.). J. Fish. Res. Board Can., 15: 12169-1311.

NEILSON, J. D., and W. R. BOWERING. 1989. Minimum size regulations and the implications in the Canadian Atlantic halibut (Hippoglossus hippoglossus) fishery. Can.
J. Fish. Aquat. Sci., 46: 1899-1903.

NEILSON, J. D., K. G. WAIWOOD, and S. J. SMITH. 1989. Survival of Atlantic halibut (Hippoglossus hippoglossus) caught by longline and otter trawl gear. Can. J. Fish. Aquat. Sci., 46: 887-897.

NEILSON, J. D., J. F. KEARNEY, P. PERLEY, and H. SAMPSON. 1993. Reproductive biology of Atlantic halibut (Hippoglossus hippoglossus) in Canadian waters. Can. J. Fish. Aquat. Sci., 50: 551-563.

PENTTILA, J., F. NICHY, J. W ROPES, L. M. DERY, and A. JEARLD JR. MS 1988. Methods and Equipment. In: Age determination methods for Northwest Atlantic species. J. Penttila, and L. M. Dery (eds.). NOAA Tech. Rep., NMFS 72, 135 p.

PINER, K. R., and S. G. WISCHNIOWSKI. 2004. Pacific halibut chronology of bomb radiocarbon in otoliths from 1944 to 1981 and a validation of ageing methods. J. Fish. Biol., 64: 1060-1071.

POTTS, J. C., and C. S. MANOOCH III. 2002. Estimated ages of red porgy (Pagrus pagrus) from fishery-dependent and fishery-independent data and a comparison of growth parameters. Fish. Bull., 100: 81-89.

ROFF, D. A. 1982. Reproductive strategies in flatfish: a first synthesis. Can. J. Fish. Aquat. Sci., 39: 1686-1698.

SCOTT, J. S. 1982. Depth, temperature and salinity preferences of common fishes of the Scotian Shelf. J. Northw. Atl. Fish. Sci., 3: 29-39.

SCUDDER, N. P. 1887 . The salt-halibut fishery. In: The fisheries and fishery industry of the United States. Section V. History and methods of the fisheries, Vol. I, Part I. The halibut fisheries. Government Printing Office, Washington, DC. p. 9-119.

SOKAL, R. R., and F. J. ROHLF. 1981. Biometry, $2^{\text {nd }}$ ed. W. H. Freeman and Co. New York, NY, 859 p.

STOBO, W. T., J. D. NEILSON, and P. G. SIMPSON. 1988. Movements of Atlantic halibut (Hippoglossus hippoglossus) in the Canadian North Atlantic. Can. J. Fish. Aquat. Sci., 45: 484-491.

TRIPPEL, E. A., and H. H. HARVEY. 1991. Comparison of methods used to estimate age and length of fishes at sexual maturity using populations of white sucker (Catostomus commersoni). Can. J. Fish. Aquat., 48: 1446-1459.

TRUMBLE, R. J., J. D. NEILSEN, W. R. BOWERING and D. A. MCCAUGHRAN. 1993. Atlantic halibut (Hippoglossus hippoglossus) and Pacific halibut (H. stenolepis) and their North American fisheries. Can. Bull. Fish. Aquat. Sci, No. 227: 84 p.

WISE, J. P., and A. G. JENSEN. 1959. Movement of tagged halibut off New England. Trans. Am. Fish. Soc., 88: $357-358$. 